\title{
Retinol, $\beta$-carotene and oxidative stress in systemic inflammatory response syndrome
}

\author{
Carla Nogueira ${ }^{1}$, Fernanda Borges² ${ }^{2}$, Edson lameu ${ }^{3}$, Carlos Franca $^{4}$, Cíntia Letícia da Silva Rosa ${ }^{5}$, Andréa Ramalho 6* $^{*}$ \\ Doctorate - Member of the Research Center for Micronutrients at Federal University of Rio de Janeiro (UFRJ), Rio de Janeiro, RJ, Brazil \\ ${ }^{2}$ Master's degree - Member of the Research Center for Micronutrients UFRJ, Rio de Janeiro, RJ, Brazil \\ ${ }^{3}$ Doctorate - Head of the Parenteral and Enteral Nutrition Therapy Team at São Vicente de Paulo Hospital. Prof. of Medicine UFRJ, Rio de Janeiro, RJ, Brazil \\ ${ }^{4}$ Doctorate - Member of the Research Center for Micronutrients (NPqM) - UFRJ, Rio de Janeiro, RJ, Brazil \\ ${ }^{5}$ Master's degree - Member of the Research Center for Micronutrients UFRJ, Rio de Janeiro, RJ, Brazil \\ ${ }^{6}$ Doctorate - Full Professor at the Department of Social and Applied Nutrition, Institute of Nutrition - UFRJ. Director of the Research Center for Micronutrients UFRJ, Rio de Janeiro, RJ, Brazil
}

Article received: $7 / 14 / 2014$ Accepted for publication: $7 / 29 / 2014$

Correspondence: Núcleo de Pesquisa em Micronutrientes, Instituto de Nutrição, Centro de Ciências da Saúde, Universidade Federal do Rio de Janeiro (UFRJ) Address: Av. Brigadeiro Trompovwsky, $\mathrm{s} / \mathrm{n}$ $2^{\circ}$ andar, Bloco J - Ilha do Fundão Rio de Janeiro, RJ - Brasil Posta code: $21941-590$ carlafrancanut@yahoo.com.br

http://dx.doi.org/10.1590/1806-9282.61.02.116

\section{SUMmARY}

Objective: patients suffering systemic inflammatory response syndrome (SIRS) constitute a group susceptible to elevated levels of oxidative stress. This study's aim is to evaluate the state of oxidative stress and levels of serum retinol and $\beta$-carotene in these patients.

Methods: forty-six patients were divided into 2 groups: those those without diet $(G 1 ; n=18)$ and those with enteral nutritional support (G2;n=28). Serum levels of retinol and total carotenoids were measured. C-reactive protein (CRP) levels and Apache scores were also calculated. Oxidative stress was estimated by measuring thiobarbituric acid reactive substance (TBARS) levels.

Results: the patients' median age was $66.9(\mathrm{SD}=19.3)$ years. Lower concentrations of retinol and carotenoids were found in 68.6 and $66.7 \%$ of $\mathrm{G} 1$, respectively. In G2, despite average vitamin A levels being $8078+4035$, retinol and $\beta$-carotene were considered insufficient (31.2 and $33.4 \%$, respectively). No difference was noted between the 2 groups, according to the variables studied, with the exception being PCR and $\beta$-carotene ( $\mathrm{p}=0.002 ; \mathrm{p}=0.01)$.

Conclusion: the data presented in this study supports the need to establish/revise clinical practices in treating SIRS patients, in light of this micronutrient's role in the immune system and antioxidant defense without it interfering with its toxicity.

Keywords: vitamin A, oxidative stress, retinol, $\beta$-carotene, systemic inflammatory response syndrome.

\section{INTRODUCTION}

The survival of critically ill patients depends on complex and careful immune response across the entire organic system. Generally, dysfunction in immune response surfaces in two distinct ways: lowered immune response, leading to a significant increase in susceptibility to infection, and over-performance of cellular immune response, known clinically as systemic inflammatory response syndrome (SIRS). ${ }^{1}$

Alterations in concentrations of certain plasmatic proteins occur in critically ill patients, such as an increase in production of C-reactive protein (CRP) by the liver. $\mathrm{CRP}$ is one of the main acute phase proteins to have been utilized as a precocious and sensitive biomarker in responding to infectious or inflammatory processes, and it may increase 19 to 100 -fold during the first 12 hours after onset. ${ }^{2,3}$

Incidence of SIRS in clinical patients is close to $50 \%$, and to $80 \%$ in surgical patients hospitalized in ICU., ${ }^{4,5}$ When stricken with this condition, the system reacts by increasing production of reactive oxygen species (ROS) as a result of the increase in pro-inflammatory mediators. As a biological response to the presence of these species, a drop in antioxidant levels occurs, leading to an imbalance in redox capacity and, as a consequence, an increase in oxidative stress. This increase is directly related to the tissue damage suffered during response to infection. ${ }^{6}$

According to Alonso et al., ${ }^{6}$ the blood of critically ill patients exhibits lower levels of antioxidant substances, among them carotenoids, vitamins A, C and E. 
Vitamin A serves several important functions in the human body, playing a role in visual acuity, cellular proliferation and differentiation, antioxidant action and immunological activity. ${ }^{7}$ It embodies retinol and carotenoids, which are, respectively, the pre-formed vitamin and its precursors. Among these, $\beta$-carotene is recognized as the most potent precursor to retinol. ${ }^{8}$ Both its biologically-active form and its pro-vitamin forms have gained prominence for their roles in fighting ROS, protecting the body against oxidative stress and, consequently, preventing tissue damage. ${ }^{9}$ Retinol functions as an antioxidant, as it associates with peroxyl radicals before these are able to propagate peroxidation to the cellular lipid component and generate hydroperoxides. In regard to arytenoids, they neutralize peroxyl radicals and singlet oxygen. ${ }^{10,11} \beta$-carotene is the most well-known and studied carotenoid due to its antioxidant activity (five times greater than retinol), mainly for its protecting lipoprotein from low-density LDL (90\% of all carotenoids originate from $\beta$-carotene). ${ }^{12-14}$

As seen, many factors may justify insufficient serum levels of vitamin A in patients with SIRS since these individuals are highly susceptible to oxidative stress, a fact that raises considerably their intake of substances with antioxidant functions. However, so far, no studies regarding vitamin A deficiency (VAD) including groups of SIRS patients have been performed in Brazil.

In light of these findings, the aim of this study was to evaluate serum concentrations of retinol, $\beta$-carotene and oxidative stress and their relation to C-reactive protein and clinical variables in patients with SIRS, cared for at two ICUs in the city of Rio de Janeiro.

\section{Materials AND Methods}

The study included adult patients diagnosed with SIRS, according to the ACCP/SCCM Consensus Conference Committee, ${ }^{15}$ and hospitalized in the ICU of two hospitals in the city of Rio de Janeiro, over a period of six months. The patients were subsequently divided into 2 groups: patients not on special diet (G1) and those receiving enteral feeding (G2).

Patients were approached to receive nutritional support on day 2 to day 4, after which they were given the diet and supplement (patients received 90 to $100 \%$ of their dietary needs). Among those not receiving nutritional support, the time ranged from 24 to 72 hours. There was no report of diarrhea in any of the patients enlisted.

This study was approved of by the Research Ethics Committee of the Clementino Fraga Filho Teaching Hospital of the Federal University of Rio de Janeiro. Consent was granted by the patients' relatives.
Patients with chronic renal failure, cirrhosis of the liver, and pregnant women, as well as patients during immediate postoperative period were excluded, because these conditions have a direct influence on circulating and stored levels of vitamin A.

The method used for quantifying retinol and $\beta$-carotene was high performance liquid chromatography (HPLC-UV) and the values of serum retinol considered to be adequate were $\geq 1.05 \mu \mathrm{mol} / \mathrm{L}$, whereas values $<1.05 \mu \mathrm{mol} / \mathrm{L}(<30 \mu \mathrm{g} / \mathrm{dL})$ were considered vitamin A deficiency (VAD) markers suggested for investigating marginal vitamin A deficiency, due to the increased risk of morbid-mortality associated with subclinical or pre-pathological lack of this vitamin. ${ }^{16}$ The cutoff used to indicate insufficient serum values of $\beta$-carotene was $\leq 40$ $\mu \mathrm{g} / \mathrm{dL}$, as suggested by Sauberlich et al. ${ }^{17}$

Oxidative stress was determined through lipid peroxidation dosage estimated using TBARS levels in blood plasma, according to the method described by Ohkawa et al. ${ }^{18}$ CRP was assessed using nephelometry method. At the time the patients were enrolled, the Apache II score was calculated. ${ }^{19}$

Measures of central tendency and dispersion were calculated. Pearson and Spearman correlations were performed, according to the behavior of each variable; values above 0.6 were adopted as being a strong correlation, and values from 0.3 to 0.6 meant a regular correlation. Student's $t$ and MannWhitney tests were applied for comparing continuous variables. To assess the association between categorical variables, Chi-square $\left(\mathrm{c}^{2}\right)$ was applied. A 5\%-probability ( $\mathrm{p} \leq$ 0.05 ) significance level was adopted. Statistical analysis was performed by means of the SPSS for Windows statistical software (version 13; SPSS INC., Chicago, IL, USA).

\section{Results}

Forty-six individuals were studied, $54.3 \%$ being female $(n=25)$ and $45.7 \%$, male $(n=21)$. Their general characteristics are shown in Table 1.

\section{TABLE 1 General characteristics.}

\begin{tabular}{|c|c|c|c|c|c|}
\hline & Mean & Median & SD & Minimum & Maximum \\
\hline Age (years) & 66.9 & 71.0 & 19.3 & 20.0 & 93.0 \\
\hline $\begin{array}{l}\text { Retinol } \\
(\mu \mathrm{mol} / \mathrm{L})\end{array}$ & 1.0 & 0.5 & 1.1 & 0.01 & 5.35 \\
\hline $\begin{array}{l}\beta \text {-carotene } \\
(\mu \mathrm{g} / \mathrm{dL})\end{array}$ & 32.2 & 22.8 & 41.2 & 6.2 & 439.3 \\
\hline CRP $(\mathrm{mg} / \mathrm{L})$ & 153.0 & 121.1 & 111.3 & 12.2 & 439.3 \\
\hline $\begin{array}{l}\text { TBARS } \\
(\mathrm{nmol} / \mathrm{mL})\end{array}$ & 4.1 & 2.8 & 4.5 & 0.04 & 22.04 \\
\hline Apache II & 16.9 & 17.0 & 5.5 & 7.0 & 33.0 \\
\hline
\end{tabular}

ces; Apache II: Acute Physiology and Chronic Health Evaluation. 
The Apache II score mean value (16.9) revealed a 25\% probability of death in all patients.

No relationship among the continuous variables studied was found.

Although no significant association was found between concentrations of retinol and $\beta$-carotene $(p=0.34)$, the patients with insufficient retinol levels showed a greater frequency of insufficient $\beta$-carotene $(61 \%, n=28)$.

It was observed that retinol and $\beta$-carotene inadequacy was more frequent $(78 \% ; n=18$ and $74 \% ; n=17$, respectively) in patients with higher circulating levels of TBARS (allocated in $75^{\text {th }}$ quartiles).

The average offer of vitamin A to patients receiving dietetic support was $7963 \mathrm{IU} /$ day, a significantly greater value compared to the DRI (dietary reference intake) recommendation for adults by the IOM. ${ }^{20}$

The proportion of serum retinol inadequacy in the groups with and without the diet was $68.7(\mathrm{n}=22)$ and $31.2 \%(n=10)$, respectively; there was $66.7 \%(n=26)$ $\beta$-carotene inadequacy in the non-diet group, and $33.4 \%$ $(n=13)$ in the diet group. There was no significant difference between the diet $(n=18)$ and non-diet $(n=28)$ groups in terms of variables studied, except when it came to CRP and $\beta$-carotene (Tables 2 and 3 ).

\begin{tabular}{|c|c|c|}
\hline Nutritional support & With diet & Without diet \\
\hline \multicolumn{3}{|l|}{ Retinol ( $\mu \mathrm{mol} / \mathrm{L})$} \\
\hline$n$ & 18 & 28 \\
\hline Mean & 1.18 & 0.9 \\
\hline SD & 1.12 & 1.13 \\
\hline $\mathrm{P}$ & 0.25 & \\
\hline \multicolumn{3}{|l|}{$\beta$-carotene $(\mu \mathrm{g} / \mathrm{dL})$} \\
\hline$n$ & 18 & 28 \\
\hline Mean & 43.14 & 24.37 \\
\hline SD & 54.3 & 27.12 \\
\hline$P$ & $0.01^{*}$ & \\
\hline
\end{tabular}

TABLE 3 Mean values of TBARS, CRP and Apache II of patients with SIRS, according to nutritional support.

\begin{tabular}{llll} 
Nutritional support & With diet & Without diet \\
\hline TRABS $(\boldsymbol{\mu m o l} / \mathbf{m L})$ & & & \\
\hline $\mathrm{n}$ & 18 & 28 & \\
\hline Mean & 3.94 & 4.26 & \\
\hline SD & 3.89 & 4.87 & \\
\hline & & & (continue)
\end{tabular}

TABLE 3 (Cont.) Mean values of TBARS, CRP and Apache II of patients with SIRS, according to nutritional support.

\begin{tabular}{lll} 
Nutritional support & With diet & Without diet \\
\hline $\mathrm{P}$ & 0.86 & \\
\hline CRP $(\mathbf{m g} / \mathrm{L})$ & & \\
\hline $\mathrm{n}$ & 18 & 28 \\
\hline Mean & 98.64 & 189.33 \\
\hline $\mathrm{SD}$ & 91.15 & 110.07 \\
\hline $\mathrm{P}$ & $0.002^{*}$ & \\
\hline
\end{tabular}

\begin{tabular}{lll}
\hline Apache II & & \\
\hline $\mathrm{n}$ & 18 & 28 \\
\hline Mean & 16.33 & 17.28 \\
\hline $\mathrm{SD}$ & 5.13 & 5.91 \\
\hline $\mathrm{P}$ & 0.38 & \\
\hline
\end{tabular}

${ }^{*} p<0.05 /$ Test Mann-Whitney.

\section{Discussion}

Vitamin A status and oxidative stress parameters in patients with signs of SIRS cared for in ICU were assessed, with the purpose of identifying them as a group at risk of developing VAD.

The primary cause of VAD is insufficient consumption of this vitamin, below the individual's organic needs, thus damaging the physiological functions although clinical signs of the deficiency may not be evident. ${ }^{21-24}$

The second cause of VAD is the frequency of infectious episodes. Nowadays it is known that even subclinical VAD (when xerophthalmia signs are absent) intensifies the severity of infirmities and of several infectious processes, and it may provoke immunodeficiency status of an exclusive nutritional origin added to a higher metabolic utilization of vitamin A against oxidative stress to which individuals with infectious processes are more exposed to. ${ }^{16}$

In Brazil, there is no information available as to the prevalence of VAD in patients in critical states, but it can be stated that the prevalence of VAD in the patients suffering of SIRS cared for in ICU included in this study is extremely high, justifying greater attention to this population.

In the group studied, besides the high prevalence of deficiency found in retinol and $\beta$-carotene levels, evidence of lipid peroxidation associated with high CRP levels was observed, jeopardizing even more the clinical status of these patients.

According to Mecocci et al., ${ }^{25}$ an adequate vitamin A nutritional status reduces the conversion of carotenoids into retinol, hence demonstrating that there is a relationship between the nutritional status of retinol and carotenoids. This study found that the high proportion of individuals with insufficient serum concentrations of retinol 
also presented a higher frequency of $\beta$-carotene inadequacy, although without statistical significance. This fact is worrisome because it reflects how ineffective vitamin $\mathrm{A}$ is metabolically in these patients, who rely on the antioxidant power of this vitamin to decrease the oxidative stress to which they are exposed, as well as all the vital functions carried out by this micronutrient, especially for the overall immunological system.

No association between concentrations of CRP and $\beta$-carotene were found in this study, which diverges from Boosalis et al., ${ }^{26}$ who observed that the acute phase response was significantly and negatively correlated with the circulating levels of total carotenoids. In the study by Kritchevsky et al., ${ }^{27}$ using data from the national health survey of the USA (NHANES III), an inverse relation was also found between CRP and $\beta$-carotene concentrations. This divergence could be explained by the fact that these two studies did not address the critically ill. Both studies do show, however, the need for more literature addressing critical SIRS patients, as it is difficult to compare the data presented herein.

In this study, no statistical difference was found regarding serum levels of retinol, TBARS and the Apache II score in the diet and non-diet groups. So far, there is no literature presenting results similar to those in the present study, which would enable comparisons with our findings. Nonetheless, when comparing mean serum concentrations of CRP in the diet and non-diet groups, significantly higher concentrations were found in the non-diet group, a fact possibly explained by the very absence of nutritional support contributing to increased catabolic demand. The lower concentration of circulating $\beta$-carotene concentration among patients without nutritional support may relate to its mobilization as an antioxidant in combating oxidative stress (which was greater in the non-diet group) and also due to its bioconversion, in such a way as to maintain serum retinol concentrations that, despite the insufficient concentrations in the set of patients, presented no statistically significant difference between patients with and without nutritional support. This finding leads to a reflection that the critically ill SIRS patients included in this study who did not receive a supplemented diet, would be deprived of the antioxidant power of $\beta$-carotene, given that this subgroup presented lesser average serum concentrations.

Quasim et al. ${ }^{28}$ studied 43 patients diagnosed with SIRS hospitalized in an ICU and found evidence of oxidative stress, in addition to reduced amounts of vitamin $\mathrm{E}$ and fractions of carotenoids, similar results to those found in this study.
Increased systemic pro-inflammatory reaction induced by SIRS is correlated to regulation of the individual's inflammatory response, as micronutrients recognized for acting as antioxidants and taking part in the immunological system play an important role in this response. ${ }^{29}$ It is known that in view of the occurrence of an inflammatory process without supplementation of micronutrients, there will likely be a deficiency of these micronutrients, which would further collaborate in this process. ${ }^{30}$

Preiser et al. ${ }^{31}$ studied 37 critically ill patients. Of these, 20 received vitamin A (1.915 $\mu \mathrm{g} /$ day), C and E supplementation, and 17 received a standard diet. A significant increase in serum values of $\beta$-carotene in the supplemented group was observed, such as an increase in the resistance of LDL to oxidative stress; however, no alterations were found in lipid peroxidation through TBARS doses.

Dietary reference intake (DRI) of vitamin A for adults is $900 \mu \mathrm{g} /$ day (males) and $700 \mu \mathrm{g} /$ day (females), and the $\mathrm{UL}$ (tolerable upper intake level) is $3,000 \mu \mathrm{g} /$ day. ${ }^{20}$ In this study, the mean vitamin A administered to patients was $8,079 \mathrm{UI}$, corresponding to approximately three times the recommended consumption; this suggests that the dose of vitamin A routinely offered to these patients did not meet this group's demands due to the great frequency of serum retinol and $\beta$-carotene inadequacy found in the study. Literature also reports that patients with SIRS have greater risk of developing multiple-organ dysfunction and acute respiratory distress syndrome,${ }^{32}$ conditions which are determinant of prognosis.

\section{Conclusion}

We can thus conclude that evidence of SIRS in critically ill patients is related to an increase in oxidative stress, consequently bringing about lipid peroxidation. Revision of the amount of vitamin A given to patients with SIRS becomes important to minimize factors such as lowered immunity, oxidative stress and low concentrations of antioxidant substances. All these considerations are instrumental in improving clinical practices, reducing tissue damage that could occur during this stage, and, as a result, contributing to improvement of the patient's prognosis. Studies to define appropriate cutoff points and specific recommendations for administering retinol and $\beta$-carotene to SIRS patient are needed.

\section{ACKNOWLEDGMENTS}

Pinheiro, Viviane. Student of Nutrition at the Federal University of Rio de Janeiro. 


\section{Resumo}

Retinol, $\beta$-caroteno e estresse oxidativo na síndrome da resposta inflamatória sistêmica.

Objetivo: pacientes que apresentam a síndrome da resposta inflamatória sistêmica (SIRS) constituem um grupo suscetível a níveis elevados de estresse oxidativo. O objetivo do presente estudo é avaliar o estado de estresse oxidativo e os níveis séricos de retinol e $\beta$-caroteno nesses pacientes.

Métodos: quarenta e seis pacientes foram divididos em dois grupos: aqueles sem dieta $(\mathrm{G} 1 ; \mathrm{n}=18)$ e aqueles com suporte nutricional enteral $(\mathrm{G} 2, \mathrm{n}=28)$. Foram investigadas as concentrações séricas de retinol e carotenoides totais, proteína $\mathrm{C}$ reativa, estresse oxidativo e escore Apache. $\mathrm{O}$ estresse oxidativo foi avaliado por dosagem da peroxidação lipídica e estimado por meio da dosagem de TBARS (substâncias reativas ao ácido tiobarbitúrico).

Resultados: a média de idade dos pacientes foi de 66,9 $( \pm 19,3)$. Baixas concentrações de retinol e carotenoides foram encontradas em 68,6 e 66,7\% do G1, respectivamente. No G2, a concentração sérica média de vitamina A foi de 8078 ( \pm 4035 ), e o retinol e o $\beta$-caroteno apresentaram percentual de inadequação de 31,2 e 33,4\%, respectivamente. Não foi observada nenhuma diferença entre os dois grupos, de acordo com as variáveis estudadas, com exceção do PCR e do $\beta$-caroteno ( $\mathrm{p}=0,002 ; \mathrm{p}=0,01)$.

Conclusão: os dados apresentados neste estudo indicam a necessidade de estabelecer/rever práticas clínicas no tratamento de pacientes com SIRS, tendo em conta o papel desse micronutriente no sistema imunológico e na defesa antioxidante, sem que isso interfira na sua toxicidade.

Palavras-chave: vitamina A, estresse oxidativo, retinol, $\beta$-caroteno, SIRS.

\section{REFEREnCES}

1. Crimi E, Sica V, Williams-Ignaro S, Zhang H, Slutsky AS, Ignarro L, et al The role of oxidative stress in adult critical care. Free Radic Biol Med. 2006;40(3):398-406

2. Bottoni A, Oliveira GPC, Ferrini MT, Waitzberg DL. Avaliação nutricional: exames laboratoriais. In: Waitzberg DL, editor. Nutrição oral, enteral e parenteral na prática clínica.3rd ed. São Paulo: Atheneu; 2002. v. 1, p.279-94.

3. Barroso RMV, Gallego JG, Guimarães EC, GATTI E, Emerick G, Araújo AL, et al. Standardization of procalcitonin, c-reactive protein and lactate levels in pigs submitted to laparotomy. Biosci J. 2011;27(3):433-8.

4. Robertson CM, Coopersmith CM. The systemic inflammatory response syndrome. Microbes Infect. 2006;8(5):1382-89.

5. Brun-Buisson C. The epidemiology of the systemic inflammatory response. Intensive Care Med. 2000;26(Suppl 1):S64-S74.
6. Alonso de Vega JM, Díaz J, Serrano E, Carbonell MD. Oxidative stress in critically ill patients with systemic inflammatory response syndrome. Crit Care Med. 2002;30(8):1783-86.

7. IOM - Institute of Medicine. Vitamin A. In: Dietary reference intakes for vitamin $\mathrm{A}$, vitamin $\mathrm{K}$, arsenic, boron, chromium, copper, iodine, iron, manganese, molybdenum, nickel, silicon, vanadium, and zinc. Washington (DC): National Academic Press; 2001.

8. Barreiros ALBS, David JM, David JP. Estresse oxidativo: relação entre geração de espécies reativas e defesa do organismo. Quim Nova. 2006;29(1):113-23.

9. Pinheiro MM, Ciconelli RM, Chaves GV, Aquino L, Juzwiak CR, Genaro PS, et al. Antioxidant intake among Brazilian adults - The Brazilian Osteoporosis Study (BRAZOS): a cross-sectional study. Nutr J. 2011;10(1):39.

10. Stahl W. Lipid oxidation and antioxidants. Curr Opin Clin Nutr Metab Care 2000;3(2):121-6.

11. Tesoriere L, D'Arpa D, Re R, Livrea MA. Antioxidant reactions of all-trans retinol in phospholipid bilayers: effect of oxygen partial pressure, radical fluxes, and retinol concentration. Arch Biochem Biophys. 1997;343(1):13-8.

12. Nogueira CR, Ramalho A, Lameu E, Franca CAS, David C, Accioly E. Serum concentrations of vitamin A and oxidative stress in critically ill patients with sepsis. Nutr Hosp. 2009;24(3):312-7.

13. Olson JA, Krinsky NI. Introduction: the colorful, fascinating world of the carotenoids: important physiologic modulators. FASEB J. 1995;9(15):1547-50

14. Britton G. Structure and properties of carotenoids in relation to function FASEB J. 1995;9(15):1551-8

15. Levy MM, Fink MP, Marshall JC. SCCM/ESICM/ACCP/ATS/SIS International Sepsis Definitions Conference. Crit Care Med. 2003;31(4):1250-6.

16. Sommer A. Vitamin A deficiency and its consequences: a field guide to detection and control. 3rd ed. Geneva: World Health Organization; 1995.

17. Sauberlich HE, Hodges RE, Wallace DL, Kolder H, Canham JE, Hood J. Vitamin A metabolism and requirements in the human studied with the use of labeled retinol. Vitam Horm. 1974;32:251-75.

18. Ohkawa H, Oshishi N, Yagi K. Assay for lipid peroxides in animal tissues by thiobarbituric acid reaction. Anal Biochem. 1979;95(2):351-8.

19. Knaus WA, Draper EA, Wagner DP, Zimmerman JE. Apache II: a severity of disease classification system. Crit Care Med. 1985;12(10):818-29.

20. Institute of Medicine (IOM). Vitamin A. In: Dietary reference intakes for vitamin $\mathrm{A}$, vitamin $\mathrm{K}$, arsenic, boron, chromium, copper, iodine, iron, manganese, molybdenum, nickel, silicon, vanadium, and zinc. Washington (DC): National Academic Press; 2004.

21. OMS (Organizacion Mundial de la Salud). Prevención y tratamiento de la carencia de vitamin A y de la xeroftalmia. Ginebra; 1982. (Série Informes Técnicos n. 672)

22. Underwood BA. Estrategias a largo plazo para el control de las deficiencias de micronutrientes. Vitamin A - Field Support Project (VITAL). Arlington: USAID; 1993. (Informe IN-14, p. 70-6)

23. World Health Organization (WHO). Global prevalence of vitamin A deficiency. Micronutrient Deficiencies Information System - Working Paper n.2.Geneva: World Health Organization; 1995. (Document WHO/NUT/95.3)

24. Ramalho RA, Flores H, Accioly E, Saunders C. Associação entre deficiência de vitamina A e situação sociodemográfica de mães e recém-nascidos. Rev Assoc Med Bras. 2006;52(3):10-7.

25. Mecocci P, Polidori C, Troiano L. Plasma antioxidants and longevity: a study of health centenarians. Free Radic Biol Med. 2000;28(8):1243-8.

26. Boosalis MG, Snowdon DA, Tully CL, Gross MD. Acute phase response and plasma carotenoid in older women: findings from the nun study. Nutrition. 1996;12(7-8):475-78.

27. Kritchevsky SB, Bush AJ, Pahor M. Serum carotenoids and markers of inflammation in nonsmokers. Am J Epidemiol. 2000;152(11):1065-71.

28. Quasim T, McMillan DC, Talwar D, Sattar N, O'Reilly J, Kinsella JL. Concentrations of carotenoids in the critically ill patient are related to a systemic inflammatory response and increased lipid peroxidation. Clin Nutr. 2003;22(5):459-62.

29. Takei M, Kobayashi M, Herndon DN, Pollard RB, Suzuki F. Glycyrrhizin inhibits the manifestations of anti-inflammatory responses that appear in association with systemic inflammatory response syndrome (SIRS) -like reactions. Cytokine. 2006;35(5-6):295-301.

30. Fuhrman MP. Antioxidant supplementation in critical illness: what do we know? Nutrition. 2000;16(6):470-1.

31. Abilés J, Cruz AP, Castaño J, Rodríguez ME, Aguayo E, Torres RM, et al. Oxidative stress is increased in critically ill patients according to antioxidant vitamins intake, independent of severity: a cohort study. Crit Care. 2006;10(5):146.

32. Fujishima S, Morisaki H, Ishizaka A, Kotake Y, Miyaki M, Yoh K, et al. Neutrophil elastase and systemic inflammatory response syndrome in the initiation and development of acute lung injury among critically ill patients. Biomed Pharmacother. 2008;62(7):333-8 